\title{
University students' social interaction type specifics in the learning process
}

\author{
Olga Rodina ${ }^{1, *}$, Liubov Gladkova ${ }^{2}$, Olga Selivanova ${ }^{2}$ \\ ${ }^{1}$ Department of Foreign Languages, Tyumen industrial university, 625000, Tyumen, Russia \\ ${ }^{2}$ Department of General and Social Pedagogy, Tyumen State University, 625003, Tyumen, Russia
}

\begin{abstract}
The author highlights the importance of human social interaction in training university students. The paper presents an overview of the conceptual aspects of social interaction in scientific research. Based on theoretical approaches to the definition of social interaction, the paper defines "social interaction" in the context of the classroom activities. The aim of the paper is to investigate and define the first-year university students' interaction specifics in the learning process. The experiment involved 118 students from the Institute of Geology and Oil and Gas Production. On the basis of K. Thomas - Kilmann's test questionnaire focused on determining a leading interaction type in conflict situations, social interaction type specifics of the first-year students of technical specialties were determined and described.
\end{abstract}

\section{Introduction}

Social life represents a complex system of social interactions. They are present in all spheres of human activity in general and in the professional activity in particular. People interact when they participate in joint activities. In a dynamically changing world professional knowledge and skills do not guarantee successful professional activity. Today it is extremely important for any professional to be able to build effective professional and social interactions and to collaborate in a team [1-4].

At the same time, there is a tendency towards excessive individualization of human life and isolation in mordern sociaty. People prefer virtual communication in social networks to face to face communication. Similar trends are manifested in higher education. There is an intensive implementation of information technology in high school settings. The educational environment is largely based on computer and telecommunication interaction technologies such as virtual libraries, distance learning courses and etc. Besides today students prefer social networking. It influences the character, the content and the success of social interaction in the classroom. Researchers and educators [2, 5, 6] note that students experience difficulty in verbal interpersonal communications and in situations requiring joint activities and cooperation. From the first days university students are immersed in the subject context of their future professional activity, while the social context that contributes to the formation of socially valuable relationships is not fully implemented.

Thus, the above listed trends actualize the problem of studying university students' social interactions specifics in the learning process in order to resolve an existing contradiction between the need to educate socially active people who are capable of effective social interaction and the insufficient study of the phenomenon of social interaction in the learning process.

The need to resolve this contradiction has identified the problem of research, which is to describe the specifics of technical university students' social interaction in the learning process in order to purposefully develop an ability to interact effectively in social and professional situations of future professional activity.

A considerable amount of research is devoted to the problem of social interaction. The first serious discussions and analyses of the concept "social interaction" as conscious, rational, people-oriented social actions emerged due to M. Weber [7]. A significant contribution to the development of the concept of social interaction was made by J. Homans, P. Blau, J. Coleman, J. Mead, G. Blumer, and A. Schütz [8]. Social interaction has been defined as a process of interchange when participants receive benefits (J. Homans, P. Blau, social exchange theory) [8], a process of coordinating the actions of people seeking to achieve individual goals (J. Coleman, rational choice theory) [8]; the process of adjusting the actions of people towards others by interpreting them (J. Mead, G. Bloomer, symbolic interactionism) [8]; the process of coordinating the actions of people who give each other's actions a meaning that is typical for their life experience (A. Schütz, a phenomenological approach) [8].

In modern scientific research the phenomenon of social interaction is a subject of many sciences and each science highlights its own aspect.

In philosophy N. L. Vinogradova, V. I. Kemerov study interaction in the context of human existence [9; 10]. Researchers [9-12] characterise interaction as cause

\footnotetext{
* Corresponding author: o_rodina2605@mail.ru
} 
and effect relationships, internal mutual activity, and close interdependence.

In sociology interaction is a social phenomenon characterized as an exchange of collective experience, knowledge, thoughts and "interpersonal relations" [11], "a form of social communication" [12], "regular actions with causal relationships". Mutual activity of interacting parties, interconnection of attitudes and value orientations, structural and functional social dependence within organisation, intentional dependence within interpersonal relations are determined as interaction's characteristics [13].

In psychology the first group of authors considers social interaction in the context of activity and they understands it as a joint activity of people to fulfil a common task (V.N. Panfyorov) [14] and as an individual "contribution" to a common activity (A.A. Leontiev) [15]. The second group of authors studies social interaction from the standpoint of the category of behavior and considers social interaction as an interactive part of communication (B. D. Parygin) [16], as a mutual influence, a process of perception and understanding each other (A. A. Bodalev) [17], a form of reality reflection (V.N. Myasishchev) [18] as a condition for effective human activity (A. P. Panfilov) [19].

There are several pedagogical approaches to understanding the phenomenon of social interaction in the learning process. From the position of the first approach, researchers V.I. Zagvyazinsky, I.N. Emelyanova [20] define interaction as a mutual activity of interacting parties. A.V. Kandaurova [21] interprets interaction as any act of a teacher's activity that causes a reciprocal action and forms social relations. The researchers of the second approach such as $\mathrm{N}$. V. Kovchin, V. V. Ignatov, and other consider social interaction as an exchange of information, values and experience in the process of joint professionally oriented activities and communication. In the third approach E. V. Kharitonova [22] interprets social interaction as a way of social self-development of individuals in the process of accomplishing a common task. I.R. Gainutdinova [23] considers social interaction as a process of environmental transformation and underlines a person's social activity, initiative, creativity, independence as conditions of social interactions. Table 1 shows a summary of social interaction definitions.

Researchers point out that there are several forms of social interactions in the process of accomplishing a common task. It is competition, cooperation, compromise, adaptation, avoidance (K. Tomas), cooperation, competition, conflict (P. Sorokin). Considering social interaction as an exchange, $\mathrm{P}$. Sorokin identified it as an exchange of ideas, an exchange of will, and an exchange of emotions.

G. M. Andreeva [24] interprets social interaction as joint activities and communication. She emphasizes that in joint activities and communication a person takes a special "position", which is considered as a status position, an attitude position, and a role position. She argues that there is a mix of the three positions in interactions. The coordination of the three positions depends on a person's activity in social interactions. A person's activity is defined by A. V. Petrovsky, M. G. Yaroshevsky [25] as an ability to change the surrounding reality in accordance with needs, attitudes, and goals [22].

Table 1. Summary of social interaction definitions.

\begin{tabular}{|c|c|}
\hline Authors & Social interaction definition \\
\hline M. Weber & $\begin{array}{l}\text { conscious, rational, people-oriented social } \\
\text { actions }\end{array}$ \\
\hline $\begin{array}{l}\text { J. Homans } \\
\text { and } \\
\text { P. Blau }\end{array}$ & $\begin{array}{l}\text { a process of interchange when participants } \\
\text { receive benefits }\end{array}$ \\
\hline J. Coleman & $\begin{array}{l}\text { a process of coordinating the actions of } \\
\text { people seeking to achieve individual goals }\end{array}$ \\
\hline $\begin{array}{lr}\text { J. } & \text { Mead } \\
\text { and } & \text { G. } \\
\text { Bloomer } & \\
\end{array}$ & $\begin{array}{l}\text { process of adjusting the actions of people } \\
\text { towards others by interpreting them }\end{array}$ \\
\hline A. Schütz & $\begin{array}{l}\text { the process of coordinating the actions } \\
\text { of people by giving them a meaning that is } \\
\text { typical for their life experience }\end{array}$ \\
\hline $\begin{array}{c}\text { N. L. } \\
\text { Vinogradova, } \\
\text { V. I. } \\
\text { Kemerov }\end{array}$ & $\begin{array}{l}\text { cause and effect relationships, internal } \\
\text { mutual activity, and close interdependence }\end{array}$ \\
\hline $\begin{array}{l}\text { G. V. Osipov } \\
\text { and } \\
\text { L. N. } \\
\text { Moskvichev }\end{array}$ & $\begin{array}{c}\text { an exchange of collective experience, } \\
\text { knowledge, thoughts and interpersonal } \\
\text { relations }\end{array}$ \\
\hline $\begin{array}{l}\text { N.L. } \\
\text { Gvishiani, N. } \\
\text { L. Lapin } \\
\end{array}$ & a form of social communication \\
\hline $\begin{array}{l}\text { V. G. } \\
\text { Kharcheva }\end{array}$ & regular actions with causal relationships \\
\hline $\begin{array}{c}\text { V.N. } \\
\text { Panfyorov }\end{array}$ & $\begin{array}{l}\text { a joint activity of people to fulfil a common } \\
\text { task }\end{array}$ \\
\hline $\begin{array}{c}\text { A.A. } \\
\text { Leontiev }\end{array}$ & $\begin{array}{l}\text { an individual contribution to a common } \\
\text { activity }\end{array}$ \\
\hline B. D. Parygin & an interactive part of communication \\
\hline $\begin{array}{l}\text { A. A. } \\
\text { Bodalev }\end{array}$ & $\begin{array}{l}\text { a mutual influence, a process of perception } \\
\text { and understanding each other }\end{array}$ \\
\hline $\begin{array}{l}\text { V.N. } \\
\text { Myasishchev }\end{array}$ & a form of reality reflection \\
\hline $\begin{array}{c}\text { G. M. } \\
\text { Andreeva }\end{array}$ & joint activity and communication \\
\hline $\begin{array}{l}\text { V.I. } \\
\text { Zagvyazinsky } \\
\text { and I.N. } \\
\text { Emelyanova }\end{array}$ & a mutual activity of interacting parties \\
\hline $\begin{array}{c}\text { A.V. } \\
\text { Kandaurova }\end{array}$ & $\begin{array}{l}\text { any act of a teacher's activity that causes a } \\
\text { reciprocal action and forms social relations }\end{array}$ \\
\hline $\begin{array}{l}\text { E. V. } \\
\text { Kharitonova }\end{array}$ & $\begin{array}{l}\text { a way of social self-development of } \\
\text { individuals in the process of accomplishing } \\
\text { a common task. }\end{array}$ \\
\hline $\begin{array}{l}\text { I.R. } \\
\text { Gainutdinova }\end{array}$ & a process of setting transformation \\
\hline
\end{tabular}

V. A. Petrovsky [25] substantiates a special type of a person's activity manifestation. It is "an over situational activity". It is defined as "a person's ability to rise above 
the level of situation requirements, set goals that are redundant from the point of view of the initial task". According to E. V. Korotaeva [26], four types of educational activity and corresponding positions are distinguished in the learning activity. It is a zero activity (expressed object position), a situational activity (mainly object activity), a performing activity (mainly subject position), and a creative activity (expressed subject position).

This paper interprets social interaction in the context of the learning process as a mutual activity of the interacting parties, which is realized in joint activities and communication and characterized by an interchange of information, values, experience, emotions, mutual coordination of actions aimed at a constructive solution of social and professional tasks. Collaborating, compromising, accommodating, avoiding are determined as social interaction types in the learning process.

\section{Materials and methods}

K. Thomas-Kilmann's test questionnaire was used to determine a leading interaction type of the first-year university students. Each respondent was asked to choose the judgment that is the most typical for his/her behaviour in a given period of study. The number of points scored by the respondent on each scale gives an idea of his/her leading interaction type (competition, cooperation, compromise, avoidance, adaptation).

The experiment involved 118 students from the Institute of Geology and Oil and Gas Production in the field of "Geological Exploration Technology", "Applied Geology". The participants were the first-year students aged between $18-19$ years old with diverse social and demographic status, lived in the city and in the countryside, graduates of special and ordinary schools with some work experience before entering the university or without any work experience.

\section{Results}

On the basis of K. Thomas - Kilmann's test questionnaire focused on determining a leading interaction type in a conflict situation, we established social interaction specifics of the first-year students of technical specialties. The study showed that in the first months of the learning process the first-year students' choose collaborating, compromising, accommodating, avoiding as interaction types. The results are shown in Figure 1.

University students' social interaction type specifics in the learning process are described below.

1. The first type of social interaction is "collaborating". Students $(18,15 \%)$ are open to communication; they take the initiative in order to establish and maintain contacts with lecturers and classmates. They have a creative approach to do their homework; they willingly give a report. They willingly participate in joint activity, they show empathy, reflection, goodwill in relationships, they do not have difficulty to ask for help and render help without delay. They willingly participate in disputes, present and defend their point of view on any issues. Students act as "generators" of new ideas in the process of joint activities and communication [27].

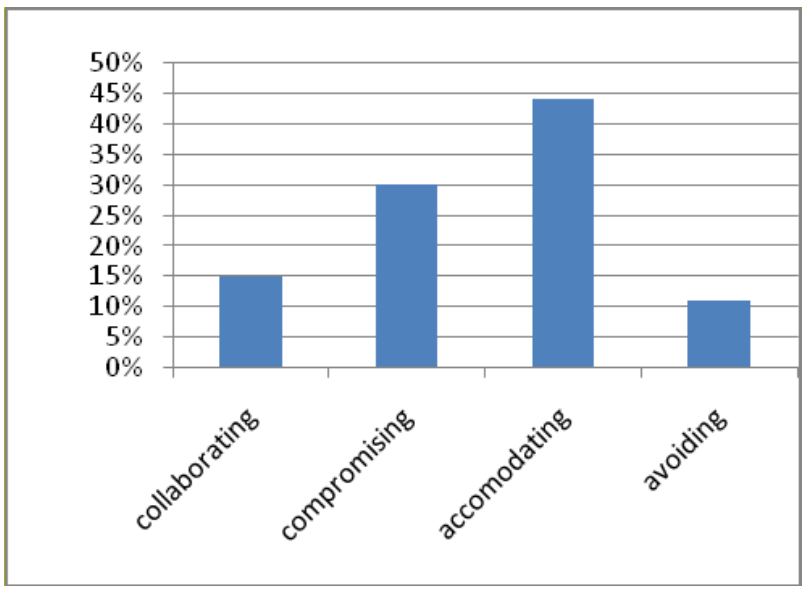

Fig. 1 Distribution of the university students by social interaction types in the learning process.

2. The second type of social interaction is "compromising". In the classroom students $(35,30 \%)$ establish and maintain contacts on the basis of personal motives. They do not show an excessive initiative in educational and extracurricular activities. Their home tasks are more of a template. A request to deliver a report or present information to the group mates causes confusion or displeasure. They do not show a desire to participate in joint work and communication. They show stiffness in the relationship. Openness in communicating with other people depends on the situation of social interaction. They express their point of view, ideas at the request of the lecturer. They rarely ask for help. The need for new contacts puts them off balance. Communicative and organizational skills are poorly expressed. They tolerate an exchange of views, but feel uneasy, because they do not have their attitude position; their behaviour depends on concessions from another person.

3. The third type of social interaction is "accommodating". Students $(52,44 \%)$ do not have complete information about the environment (rules, regulations, interactions, etc.). They do not prefer showing an excessive activity. In the classroom they establish and maintain contacts on the basis of cognitive motives. They do not take the initiative in educational and extracurricular activities. They try to complete tasks, but they are more of a template. A request to deliver a report, or present any information to the group causes confusion or displeasure. They do not show a desire to participate in joint work. They show stiffness in the relationships. Openness in communicating with other people depends on the situation of social interaction. They express their point of view, ideas only at the request of the teacher. They rarely ask for help. The need for new contacts puts them off balance. They show indecision in critical situations. Communicative and organizational skills are poorly expressed. They are ready to sacrifice their interests and give in to another 
person in order to avoid confrontation and maintain good relationships with others [27].

4. The fourth type of social interaction is "avoiding". Students $(13,11 \%)$ do not show activity in social interactions. They do not establish contacts with teachers and group mates in the classroom. Homework is rarely done but, when it is done, it is of a template. They avoid making a report or present any information to the group. In joint activities, they try to "sit tight". They do not express their point of view, their attitude even at the request of the teacher. They refuse to engage in dialogues. Communicative and organizational skills are not expressed at all. They get out of a conflict situation without solving it.

\section{Discussion and conclusion}

The author's experience in teaching at university shows that large numbers of students are not able to cooperate in joint classroom activities. This paper reveals the relevance of studying social interaction of university students. It presents four leading types of university students' social interaction. It confirms the need to form skills, abilities, personality traits that increase the effectiveness of social interaction. University teachers can engage students in social interaction taking into account revealed social interaction type specifics. The prospect for further research is the development of educational tasks to form skills for effective social and professional interactions, taking into account the identified social interaction type specifics of the firstyear university students.

\section{References}

1. J. Trevelyan, Engineering Studies, 2, 3, 175-195 (2010). Retrieved from: https://www.tandfonline.com/doi/abs/10.1080/19378 629.2010 .520135

2. K. A. Alshare, P. L. Lane, D. Miller, Journal of Education for Business, 86, 3 (2011). Retrieved from:

https://www.tandfonline.com/doi/abs/10.1080/08832 323.2010.497819

3. D. Spencer, M. Riddle, B. Knewstubb, Higher Education Research \& Development, 31, 2, 186-194 (2012). Retrieved from: https://www.tandfonline.com/doi/abs/10.1080/07294 360.2011 .554387

4. F. J. Simon, S. Shaw, Research Papers in Education, 34, 3, 276-297 (2018). Retrieved from: https://www.tandfonline.com/doi/abs/10.1080/02671 522.2018.1424928

5. M. V. Bulanova-Toporkova, Pedagogy and psychology of higher education. A series of "Textbooks, teaching aids (Phoenix, Rostov-on-Don, 1998)

6. N. M. Kodintseva, The relationship of competence of social interaction and psychological characteristics of university students, dissrtation, (Moscow, 2009)

7. M. Weber, Selected Works (Moscow, 1990)

8. D. V. Ivanov, Yu.A. Asochakov, Sociology: a textbook (Moscow, 2000)

9. N. L. Vinogradova, Social interaction as an object of philosophical analysis, dissertation, Candidate of Philosophy Sciences,(Volgograd 1999)

10. V. E. Kemerov, Society, social, polysubject (Moscow Academic Project, Peace Foundation, 2012)

11. G.V. Osipov, L.N. Moskvichev, Sociological Dictionary (Moscow, 2010)

12. N. L. Gvishiani, N.L. Lapin, A brief dictionary of sociology (Moscow Publishing House of Political Literature, 1989)

13. V.G. Kharcheva, Fundamentals of Sociology: A textbook for students of secondary special educational institutions (Moscow, 2000)

14. V. N. Panfyorov, Fundamentals of human psychology (St. Petersburg, 2009)

15. A.A. Leontiev, Pedagogical communication, (Moscow-Nalchik, 1996)

16. V. D. Parygin, Social psychology. Problems of methodology, history and theory (1999)

17. A. A. Bodalev, The perception and understanding of man by man (Moscow Publishing House, 1982)

18. V. N. Myasishchev, Relationship Psychology: Selected Psychological (Moscow: Institute of practical psychology, 1995)

19. A. P. Panfilov, Psychology of communication: a textbook for students (Moscow Publishing Center "Academy", 2013)

20. V. I. Zagvyaznsky, I.N. Emelyanova, General Pedagogy (Moscow, High School, 2008)

21. A.V. Kandaurova, Strategies and levels of social interaction in teaching. Man and education , 37, 4 (2013)

22. E.V. Kharitonova, Formation of the experience of the social interaction of a teenager in the institution of children's extracurricular education. Dissertation, Candidate of Pedagogical Sciences, Orenburg (2011)

23. I.R. Gainutdinova, Formation of readiness of high school students for social interaction as a condition for their successful socialization, Dissertation, Candidate of Pedagogical Sciences, Saratov (2010)

24. G.V. Andreeva, Social Psychology. Textbook for higher education (Moscow, Aspect Press, 2001)

25. A.V. Petrovsky, Personality. Activity. Team, (Moscow, 2007)

26. E.V. Korotaeva, Psychological foundations of pedagogical interaction: a textbook for universities (Moscow, 2007)

27. O. N. Rodina, O. A. Selivanova, Advances in Social Science, Education and Humanities Research (ASSEHR), 97, 246-249 (2017) 